\title{
Novel observations underlying the fast growth of suspension-feeding shellfish in turbid environments: Mytilus edulis
}

\author{
A. J. S. Hawkins ${ }^{1, *}$, R. F. M. Smith ${ }^{1}$, B. L. Bayne ${ }^{1}$, M. Héral ${ }^{2}$ \\ 'Plymouth Marine Laboratory, Natural Environment Research Council, West Hoe, Plymouth PL1 3DH, United Kingdom \\ ${ }^{2}$ IFREMER-LABEIM, Mus du Loup, BP 133, F-17390 La Tremblade, France
}

\begin{abstract}
For the first time for any benthic filter-feeder, this study documents each component process of nutrient acquisition through natural tidal variations of food availability. The organic content of seston available during both neap and spring tides in the bay of Marennes-Oléron, France, decreased from 28 to $8 \%$ with increasing seston concentration from 10 to about $90 \mathrm{mg}$ total particulate mass $l^{-1}$ Throughout this tidal variation, the blue mussel Mytilus edulis L. cleared more water of particles as seston availability increased. Rejection of filtered material as pseudofaeces prior to ingestion remained a constant fraction of about $0.93 \times$ the mass of filtered material, so that ingestion rate showed no signs of stabilising at even the highest food availabilities. We confirm that $M$. edulis may preferentially reject inorganic matter with pseudofaeces. More significant was the novel observation that the net selection efficlency with which filtered organics were selectively retanned for ingestion increased rapidly with the rate at which seston was filtered, this increase being faster for seston of higher organic content. The result was that the organic content of ingested matter was enriched by up to 5 times the organic content of filtered particles. Further, net absorption efficiency for ingested organics varied in strong positive relation with the organic content of ingested material. Therefore, rates of organic absorption increased with seston filtration rate, and net energy balance increased despite the decreasing organic content of particles available at higher concentrations. These collective findings demonstrate continuous interrelated changes in feeding physiology that help to maintain rates of nutrient acquisition independent of short-term fluctuations in seston composition.
\end{abstract}

KEY WORDS: Seston composition - Tidal variation - Mussel - Mytilus edulis - Feeding behaviour . Selection efficiency Absorption efficiency - Net energy balance

\section{INTRODUCTION}

Mussels and other suspension-feeding bivalve molluscs often live in nearshore environments, where particulate matter suspended as seston may comprise a highly variable mixture of algal cells, detritus and silt (Bayne \& Widdows 1978, Widdows et al. 1979, Héral et al. 1983, Rodhouse et al. 1984, Smaal et al. 1986, Fegley et al. 1992, Cranford \& Hargrave 1994). Within these environments, there is an increasing pressure to predict the carrying capacity for shellfisheries, and to validate hypotheses on the role of suspension-feeders in coastal

·E-mail: a.hawkins@pml.ac.uk

C Inter-Research 1996

Resale of full article not permitted ecosystem dynamics (e.g Dame et al. 1980, Cloern 1982, Officer et al. 1982, Doering \& Oviatt 1986, Asmus \& Asmus 1991, 1993, Bayne \& Hawkins 1992, Dame 1993, Héral 1993, Herman 1993, Smaal \& Prins 1993). To help bring understanding to the relevant processes, there have been many studies of how changes in both the abundance and composition of seston affect the suspension-feeding behaviour of bivalve molluscs (see reviews by Winter 1978, Bayne \& Newell 1983 , Hawkins \& Bayne 1992, Bayne 1993, Navarro \& Iglesias 1993; and recent papers by Cranford \& Gordon 1992, Cranford \& Grant 1992, Iglesias et al. 1992, Navarro et al. 1992, 1994, Barillé et al. 1993, in press, Bayne et al. 1993, Newell \& Shumway 1993, Cranford \& Hargrave 1994, Prou et al. 1994). 
Most of these studies have used artificial diets comprised, at least in part, of unicellular algal monocultures. However, it is now recognised that very different responses are observed in bivalves feeding upon natural suspensions of lower organic content (FosterSmith 1975, Cranford \& Gordon 1992, Iglesias et al. 1992. Navarro et al. 1992, Bayne et al. 1993). Applying different models of feeding behaviour to field populations of bivalves, only those based on data that had been collected from bivalves feeding upon natural suspensions of particulates yielded predictions that were in good agreement with observed processes (Doering \& Oviatt 1986)

The main reason for this discrepancy appears to be related to the relative proportions of food and nonutilisable matter within available seston. Traditionally, it has been thought that high concentrations of silt and other inorganics may overload the filtering mechanism and limit by 'dilution' the amount of food material ingested (Jørgensen 1966, Widdows et al. 1979). However, the addition of silt to artificial algal diets has been seen to enhance growth in suspension-feeding bivalves, stemming from greater organic absorption associated with faster clearance rate (volume of water cleared of particles $\mathrm{h}^{-1}$ ) and/or higher absorption efficiency (Winter 1976, Griffiths 1980, Kiørboe et al. 1980, 1981, Møhlenberg \& Kiørboe 1981). It has also been established that suspension-feeding bivalves may compensate for the 'dilution' of food material by selective pre-ingestive rejection of filtered. inorganic material as pseudofaeces, thereby preferentially retaining organic matter for ingestion (Kiørboe et al. 1980, Kiørboe \& Møhlenberg 1981. Newell \& Jordan 1983, Bricelj \& Malouf 1984, Bayne et al. 1989, 1993, Prins \& Smaal 1989, Prins et al. 1991, Cranford \& Gordon 1992, Deslous-Paoli et al. 1992, Iglesias et al. 1992, Navarro et al. 1992, Barillé \& Prou 1994). Indeed, experimental evidence from laboratory experiments now suggests that high rates of clearance and pseudofaeces production will maximise energy gain when feeding upon natural suspensions, offering the potential for pre-ingestive selection, but not when such selection is irrelevant (Iglesias et aI. 1992. Navarro et al. 1992, Bayne et al. 1993). This appears to explain many of the different responses observed between bivalves feeding upon algae-enriched and natural seston. For example, clearance rate has declined with increasing availability of diets that are either pure algae (e.g Davids 1964, Winter 1973. Foster-Smith 1975) or pure inorganics (Cranford \& Gordon 1992), whereas rates of both feeding and absorption have been stimulated upon addition of silt to algae (Winter 1976, Griffiths 1980, Kiorboe et al. 1980, 1981, Møhlenberg \& Kurboe 1981), and remained nearly constant in response to the increasing availability of mixed diets of low organic content (Iglesias et al. 1992).

Pre-ingestive selection thus seems to be a central process underlying suspension-feeding behaviour in bivalve molluscs. Recent studies have sugcrested that the efficiency of that selection may vary accurding to diet composition (Iglesias et al. 1992, Bayne et al. 1993, Barillé \& Prou 1994) but remain independent of food availability (Kiørboe et al. 1980, Prins et al. 1991, Iglesias et al. 1992, Navarro et al. 1992). However, these comparisons have all been made between controlled experimental conditions of fixed seston abundance and composition, which have generally been enriched with cultured algae. Very few studies have monitored immediate responses to natural tidal variations in food availability. Working in the bay of Marennes-Oléron, France, Barillé \& Prou (1994) showed that selection efficiency in the oyster Crassostrea gigas increased both with seston organic content and with seston abundance, at all but the highest concentrations. And, at the same site, Prou et al. (1994) monitored the influence of natural variations in seston concentration upon average rates of feeding $\left(\mathrm{l} \mathrm{h}^{-1}\right)$ by a single group of approximately 250 mussels Mytilus edulis which were maintained collectively within a single raceway. The present paper also describes feeding behaviour in $M$. edulis that were exposed to the same natural tidal variations in food availability, coincidentally with the work of Prou et al. (1994). However, we worked with individual mussels that were each maintained within a separate raceway. And, to enable an integrated appraisal of observed behaviour in terms of net energy balance, we monitored additional processes that included clearance rate, selection efficiency, ingestion rate and absorption efficiency. During the course of these measurements, variable currents caused tidal variations in seston abundance (15 to $83 \mathrm{mg}$ total dry wt $\mathrm{l}^{-1}$ ) that were almost as great as the corresponding seasonal range ( $<95 \mathrm{mg}$ total dry $\mathrm{wt}^{-1}$ ) measured over an entire year at a nearby site (Deslous-Paoli et al. 1990). We document novel findings that (1) establish the fundamental importance of selection processes for $M$. edulis in the natural environment and (2) demonstrate continuous interrelated changes in feeding physiology that help to maintain rates of nutrient acquisition independent of short-term fluctuations in seston composition.

\section{MATERIALS AND METHODS}

Mussels Mytilus edulis L. were collected from Normandy, France, and transferred for acclimation within a plastic mesh bag that was fixed to the mud-flat at about mid-tide level under the outer end of the pier at Point Les Chapus in the bay of Marennes-Oléron, 
France. Starting 10 d later, physiological processes were monitored in those mussels throughout each of 4 natural tidal cycles. Of those cycles, 2 were at spring tides and 2 were at neap tides. On each occasion, about $1 \mathrm{~h}$ before the tide came in, a fresh group of mussels was transferred from the mud-flat to a temporary field laboratory on the pier above. Each of 10 individual mussels was maintained in a separate plastic tray that was supplied with seawater $\left(19.8 \pm 1.0^{\circ} \mathrm{C}\right)$ pumped from the site of acclimation at rates of 150 to $200 \mathrm{ml}$ $\mathrm{min}^{-1}$ These rates were sufficient to ensure that volumes of suspended particles determined using a Coulter Multisizer were not reduced by more than an average of $40 \%$ between the inflow and outflow from each mussel tray. For each mussel, a glass cover slip was positioned on a ball of putty (Futex) so as to separate the true faeces from material that was rejected as pseudofaeces prior to ingestion. At intervals of 1 to $4 \mathrm{~h}$ during each tidal cycle, samples of suspended particles from the outflow of empty 'control' trays, as well as all true faeces and all pseudofaeces from each individual mussel, were each collected separately. Faecal samples were homogenised by rapid repeat-pipetting within a standard volume $(22 \mathrm{ml})$ of membrane-filtered $(0.45 \mu \mathrm{m})$ seawater, and aliquots of both seawater and faecal samples filtered onto separate pre-weighed and ashed Whatman GFC filters. All filters were dried at $60^{\circ} \mathrm{C}$ before re-weighing, and calculations of the total dry sample weight per filter were made. Each filter was then ashed at $450^{\circ} \mathrm{C}$ for 4 h prior to final weighing, allowing further calculation of both the ash (inorganic) and ash-free (organic) masses of each filtered sample.

Dietary abundance was defined in terms of total particulate mass (TPMi $\mathrm{mg} \mathrm{l}^{-1}$ ), and dietary quality was defined as the organic content calculated as the fraction of that TPM which was comprised of organic matter (OC; fraction).

Processes of feeding and absorption were calculated as follows: (1) clearance rate $\left(C R ; 1 \mathrm{~h}^{-1}\right)=(\mathrm{mg}$ inorganic matter egested both as true faeces and pseudofaeces $\left.\mathrm{h}^{-1}\right) \div\left(\mathrm{mg}\right.$ inorganic matter available $\mathrm{I}^{-1}$ seawater); (2) filtration rate $\left(F R_{i}\right.$ total $\left.\mathrm{mg} \mathrm{h}^{-1}\right)=(\mathrm{mg}$ inorganic matter egested both as true faeces and pseudofaeces $\left.\mathrm{h}^{-1}\right) \times$ [(mg total particulates $]^{-1}$ seawater $) \div(m g$ inorganic matter $\mathrm{l}^{-1}$ seawater)]; (3) rejection rate $\left(R R_{i}\right.$ total $\mathrm{mg}$ $\mathrm{h}^{-1} \mathrm{j}=\mathrm{mg}$ total pseudofaeces egested $\mathrm{h}^{-1} ;$ (4) net organic selection efficiency (NOSE; fraction) $=[1-$ (organic fraction within pseudofaeces $) \div$ (organic fraction within total particulates available in seawater)]: (5) net organic ingestion rate $\left(N O I R\right.$; $\left.\mathrm{mg} \mathrm{h}^{-1}\right)=[F R \times$ (organic fraction within total particulates available in seawater) $]-[R R \times$ (organic fraction within pseudofaeces)]; (6) net organic absorption rate $\left(N O A R_{i} \mathrm{mg} \mathrm{h}^{-1}\right)=$ NOIR - [(mg total true faeces egested $\left.\mathrm{h}^{-1}\right) \times$ (organic fraction within true faeces)]; (7) net absorption effi- ciency from filtered organics (NAEFO; fraction) = INOAR $\div(F R \times$ organic fraction within total particulates available in seawater)]; (8) net absorption efficiency from ingested organics (NAEIO; fraction) = $N O A R \div$ NOIR; and (9) organic content of ingested matter $\left(O C I_{\text {; }}\right.$ fraction $)=N O I R \div(F R-R R)$.

Note that $C R$ is calculated assuming $100 \%$ retention efficiency of all particles on the gills. This is not true, for retention efficiency in mussels decreases progressively from $100 \%$ for particles of about $4 \mu \mathrm{m}$ to less than 30\% for particles smaller than $1 \mu m$ (Lucas et al. 1987, Riisgård 1988). However, for all particles suspended at Point Les Chapus during these experiments, (1) the mean equivalent spherical diameter was more than $5 \mu \mathrm{m}$, (2) more than $90 \%$ of the total seston volume was comprised of particles with equivalent spherical diameters greater than $4 \mu \mathrm{m}$ and (3) neither of these statistics changed significantly either during tides or between tides (J. Prou \& P. Soletchnik unpubl. data). Therefore, the particles that were not retained will have represented a small and constant proportion of all available seston.

Also note that NOSE, NOIR, NOAR, NAEFO and NAEIO are net measures, NOSE and NOIR being influenced by mucous losses from the animal as pseudofaeces, whereas NOAR, NAEFO and NAEIO are influenced both by mucous losses as pseudofaeces and by metabolic faecal losses, which comprise endogenous materials lost from mussels and other animals following secretion, exocytosis and/or abrasion in the gut (see 'Discussion').

Gut transit times were monitored in 8 mussels that had been acclimated within natural running seawater before being fed a 20 min pulse of the alga Tetraselmis suecica (Kylin) Butcher and then supplied with more natural running seawater. Individual times to reappearance of natural brown faeces after the egestion of all green algal monoculture indicated that ingested natural seston passed through the digestive tract of mussels with an average ( \pm 2 SE) gut transit time of only $35 \pm 17 \mathrm{~min}$. In addition, particles were seen to be rejected in pseudofaeces within less than 1 min of filtration. Therefore, for the above calculations of feeding responses, particle availability was calculated as the integrated average over the corresponding periods of faecal collection, assuming no significant delay in the deposition of filtered particles, and assuming that concentrations measured in the outflows from empty 'control' trays were representative of the available particulate matter.

Following all faecal collections, the soft tissues were excised from each mussel and dried at $60^{\circ} \mathrm{C}$ before measuring total soft-body dry weight. Feeding responses were standardised to those for an equivalent individual of $1 \mathrm{~g}$ dry soft tissue weight as follows: 
$Y_{s}=\left(W_{s} / W_{e}\right)^{b} Y_{e}$, where $Y_{s}$ is the standardised parameter, $W_{\mathrm{s}}$ is the standard weight $(1 \mathrm{~g}), W_{\mathrm{e}}$ is the weight or length of the experimental animal, $Y_{e}$ is the uncorrected parameter, and $b$ is the size exponent of 0.67 for feeding processes in Mytilus edulis (Hawkins et al. 1990) This standard weight of $1 \mathrm{~g}$ dry soft tissue weight was similar to the average $( \pm 2 \mathrm{SE})$ of $1.11 \pm 0.13 \mathrm{~g}$ dry soft tissue weight for all experimental mussels.

Using established relations which describe how total heat losses are linearly related to rates of energy absorption in Mytilus edulis (Hawkins et al. 1989, Hawkins \& Bayne 1991), net energy balance (NEB; $\mathrm{J} \mathrm{h}^{-1}$ $\left.\mathrm{g}^{-1}\right)$ was calculated as $N E B=-5.8+[0.83 \times(N O A R \times$ energy content of absorbed organic matter)]. The energy content of absorbed organic matter was assumed to be $7.25 \mathrm{~J} \mathrm{mg}^{-1}$, which was calculated using data reported in a separate study describing the average energy available as food material in proteins, lipids and carbohydrates $\mathrm{mg}^{-1}$ total seston organics in the bay of Marennes-Oléron during May 1980 (Héral et al. 1983).

All statistical tests and procedures used in the analyses and presentation of data were undertaken using SYSTAT for Windows, Version 5 (SYSTAT Inc., Evanston, IL, USA). Physiological responses were related to both TPM and OC using multiple linear regression to establish any separate effects of food abundance and food composition/quality. Multiple regression models were fitted in the forward-stepping mode that entered the most significant 'predictor' at the first step, and continued adding and deleting variables to establish sequentially significant relations with the residual variances for the dependent variable, until no further variables were able to 'significantly' improve the overall fit. To help account for correlations between predictors, variables were only included as additional predictors if the probability of their correlation with the residuals was less than $2.5 \%$. To further avoid constructing multicollinear models with unstable regression coefficient estimates, tolerance (calculated as 1 minus the squared multiple correlation between a predictor and the other predictors included in a model) was set at 0.01 This meant that any variable with a tolerance of $<0.01$ was excluded from the fitted model.

\section{RESULTS}

During natural cycles of total particulate mass (TPMi $\mathrm{mg} \mathrm{l}^{-1}$ ), TPM was up to 5 times greater during the middle stages of each spring tide than during each neap tide (Fig 1). This stemmed from greater resuspension of benthic sediments by currents of more than $0.5 \mathrm{~m} \mathrm{~s}^{-1}$ during spring tides, relative to about $0.25 \mathrm{~m} \mathrm{~s}^{-1}$ during neap tides (J Prou pers. comm.)
Fig. 2 illustrates how, combining all data from both neap and spring tides, the organic content $\left(O C_{\text {: }}\right.$ fraction) of available seston decreased from a maximum of 0.28 to a minimum of 0.08 with increasing TPM up to $112 \mathrm{mg} \mathrm{l}^{-1}$, according to a negative relation that was best described by the equation.

$$
O C=0.41(0.29,0.56) \times T P M^{-0.271 \pm 0.09)}
$$

where $\mathrm{r}^{2}=0.44, \mathrm{df}=47, \mathrm{p}<0.001$, and bracketed values indicate $95 \%$ confidence limits (CL). Analysis of covariance established that there were no differences between either the intercepts $(F$-ratio $=0.29, \mathrm{p}=0.59$ ) or the exponents ( $F$-ratio $=0.36, \mathrm{p}=0.55$ ) of separate relationships between $O C$ and $T P M$ for neap and spring tides. In addition, stepwise multiple regression analyses confirmed that time after immersion was not a significant $(p>0.05)$ predictor of either clearance rate $\left(C R_{i} I \mathrm{~h}^{-1}\right)$ or $N E B$. Therefore, all data from both neap and spring tides were pooled to assess immediate responses in feeding behaviour and growth over the full range of changes in TPM and $O C$.

$C R$ was significantly associated with the TPM of available seston, according to a positive relationship that was best described by the linear equation:

$$
C R=0.60( \pm 1.03)+0.039( \pm 0.022) T P M
$$

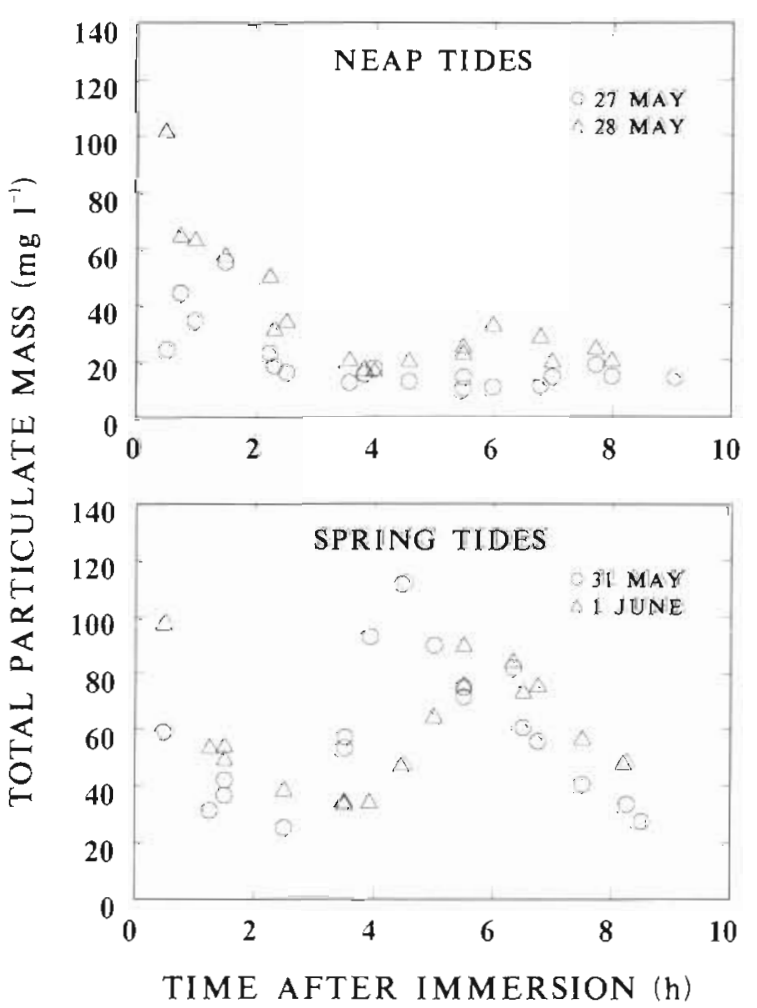

Fig. 1. Natural cycles in total particulate mass of seston over 2 neap tides and 2 spring tides at Les Chapus, France, 1992 


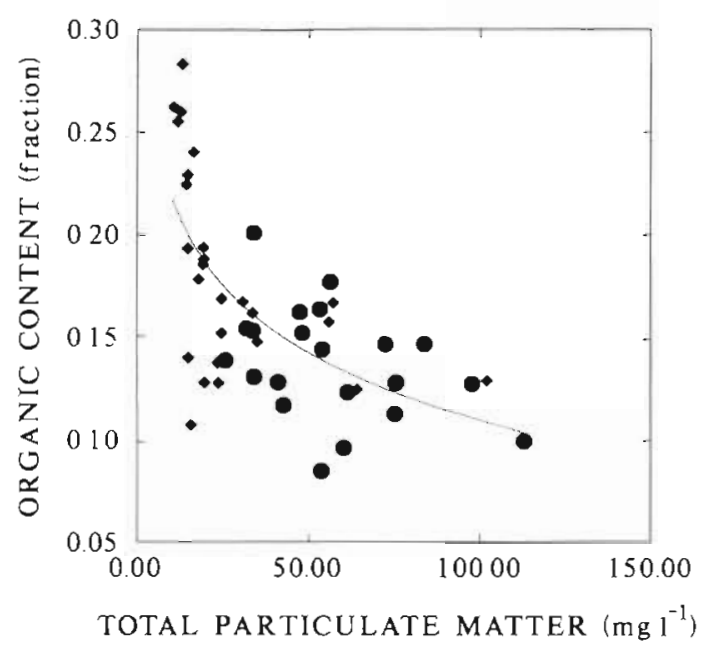

Fig. 2. Relationship between organic content and total particulate mass of avallable seston, where data were collected over 2 neap tides ( $\bullet$ ) and 2 spring tides ( $\bullet$ ). Line was fitted by least squares; refer to Eq. (1) in 'Results' for parameters and significance level

where $\mathrm{r}^{2}=0.54, \mathrm{df}=12$, and $\mathrm{p}=0.003$. Multiple stepwise regression indicated that the $O C$ of available seston did not explain any $(\mathrm{p}>0.05)$ of either the primary or remaining variance in $C R$. Therefore, $C R$ increased as a function of TPM alone.

Filtration rate $\left(F R_{\text {; total }} \mathrm{mg} \mathrm{h}^{-1}\right)$ was the main determinant of rejection rate $\left(R R_{i}\right.$ total $\left.\mathrm{mg} \mathrm{h}^{-1}\right)$, according to a strong positive relation that was best described by the linear equation:

$$
R R=-4.36( \pm 2.6)+0.93( \pm 0.02) F R
$$

where $r^{2}=0.99$, residual df $=12$, and $p<0.001$. The remaining variance in $R R$ did vary in negative relation with $O C$, but with a statistical probability of only $\mathrm{p}=$ 0.045 . Neither $R R$ nor ingestion rate $(I R=F R-R R$; total $\mathrm{mg} \mathrm{h}^{-1}$ ) showed any signs of slowing at even the highest food availabilities, when $R R$ remained a constant fraction of about $0.93 \times F R$ (Eq. 3). However, as illustrated in Fig. 3, $R R \div F R$ decreased rapidly as $F R$ fell below about $100 \mathrm{mg}$ total seston $\mathrm{h}^{-1}$ according to a relation that was best described by the exponential equation:

$$
R R / F R=92.1( \pm 4.4) \times\left(1-\mathrm{e}^{-0.049 \mid \pm 0.018)} F R\right)
$$

where $\mathrm{r}^{2}=0.99$, residual $\mathrm{df}=12$, and $\mathrm{p}<0.001$.

Multiple stepwise regression analysis showed that net selection efficiency for total organics (NOSE; fraction) was associated both with $F R$ and $O C$ according to separate significant relations that were best described by the allometric equation:

NOSE $=\left[3.88(2.28,6.59) \times F R^{0.06 ! \pm 0.03 !} \times \mathrm{OC}^{0.42 ! \pm 0.30 j}\right]-2$

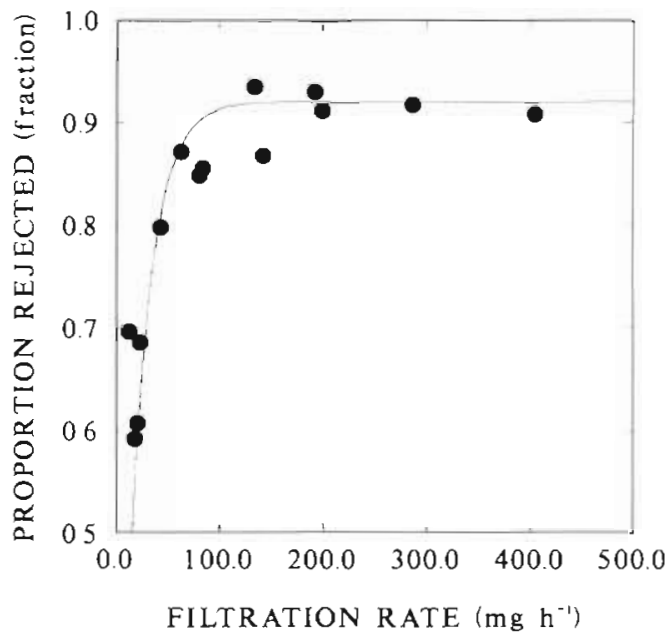

Fig. 3. Mytilus edulis. Proportion of filtered matter that was rejected as pseudofaeces in relation to filtration rate in mussels standardised to $1 \mathrm{~g}$ dry flesh weight. Data are the mean of separate determinations upon 10 replicate mussels. Line was fitted by least squares; refer to Eq. (4) in 'Results' for parameters and significance level

where $r^{2}=0.60$, residual $d f=11$, and $p<0.001$. Therefore, as illustrated in Fig 4, NOSE increased from values of approximately zero at the lowest $F R$ to maximum values of about 0.45 at the highest $F R$, this increase being much faster for mussels feeding upon seston of higher $O C$ than of lower $O C$.

Fig. 5 illustrates how the organic content of ingested matter (OCI; fraction) increased in highly significant positive relation with $F R\left(\mathrm{r}^{2}=0.77, \mathrm{n}=14, \mathrm{p}<0.001\right)$, reaching as much as 0.7 when filtering suspended particles with an $O C$ of less than 0.15. Thus, as NOSE increased with FR ( Fig. 4, Eq. 5), OCI was increasingly enriched by up to 5 times the $O C$ of filtered particles.

Net absorption efficiency from ingested organics (NAEIO; fraction) varied with $O C I$ in a strong positive relation that was best described by the exponential equation.

NAEIO $=0.99( \pm 0.21) \times\left(1-\mathrm{e}^{-4.644 \pm 0.18 \|\lfloor O C I-0.061 \pm 0.031)}\right)$

where $r^{2}=0.97$, residual $d f=12$, and $p<0.001$. This relation is illustrated in Fig 6a, showing how NAEIO increased from about 0.2 at the lowest $O C I$. The result was that as OCI increased with FR and NOSE, NAEIO increased with $I R$ in a positive relation that was best described by the exponential equation:

$$
N A E I O=0.95 \times\left(1-\mathrm{e}^{-0.22[ \pm 0.09) ![R-3.9 !(2.8))}\right)
$$

where the maximal value for NAEIO was limited to $0.95, r^{2}=0.92$, residual $\mathrm{df}=13$, and $\mathrm{p}<0.001$. This relation is illustrated in Fig. 6b, showing that NAEIO increased to near-maximal values for all IRs greater than about $15 \mathrm{mg} \mathrm{h}^{-1}$. 

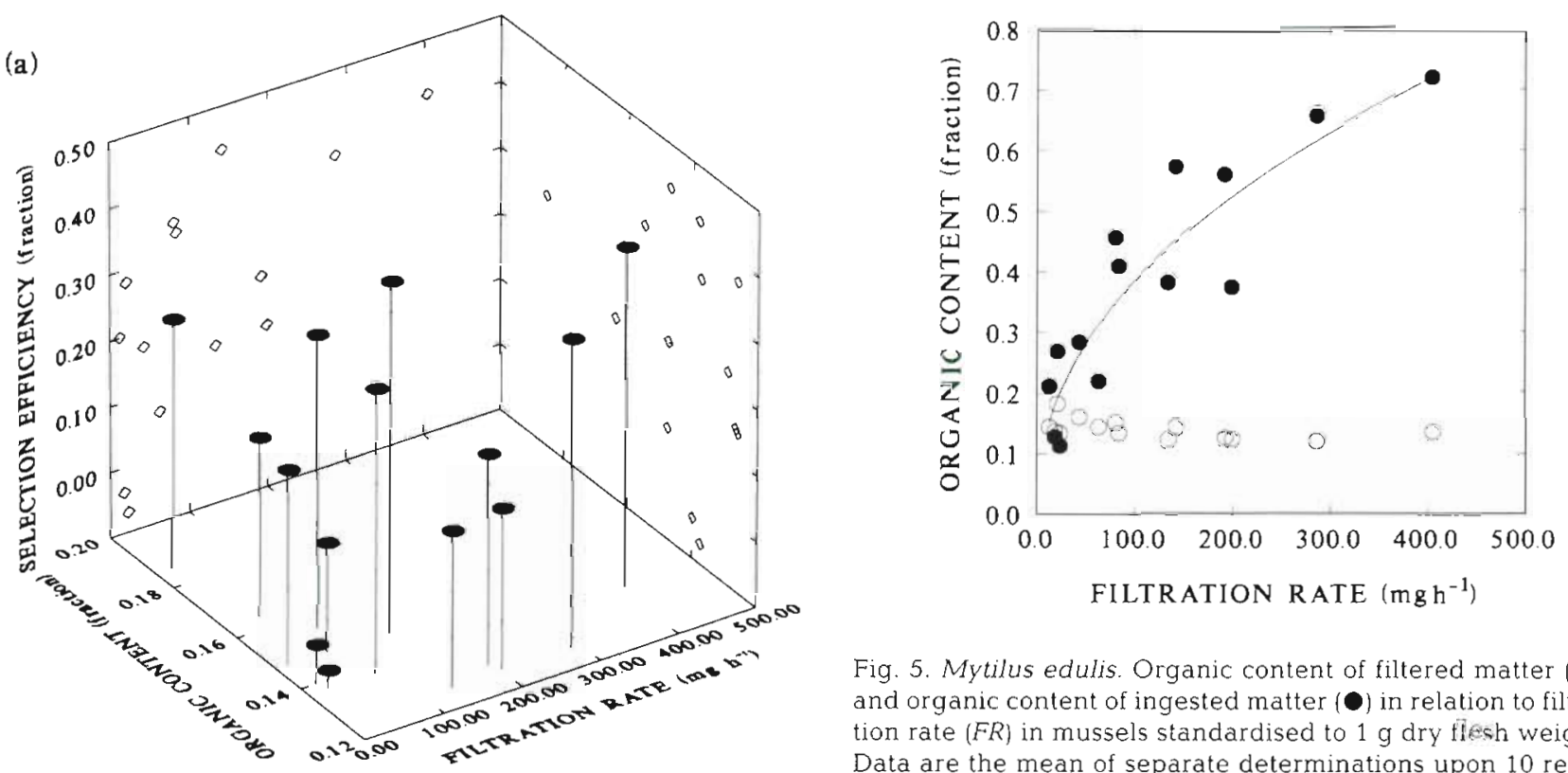

Fig. 5. Mytilus edulis. Organic content of filtered matter (O), and organic content of ingested matter $(0)$ in relation to filtration rate $(F R)$ in mussels standardised to $1 \mathrm{~g}$ dry flesh weight. Data are the mean of separate determinations upon 10 replicate mussels. Line was fitted by least squares where OCI $=$ $0.049(0.025,0.095) \times F R^{045(* 0.15)}, r^{2}=0.77, \mathrm{n}=14$, and $\mathrm{p}<0.001$

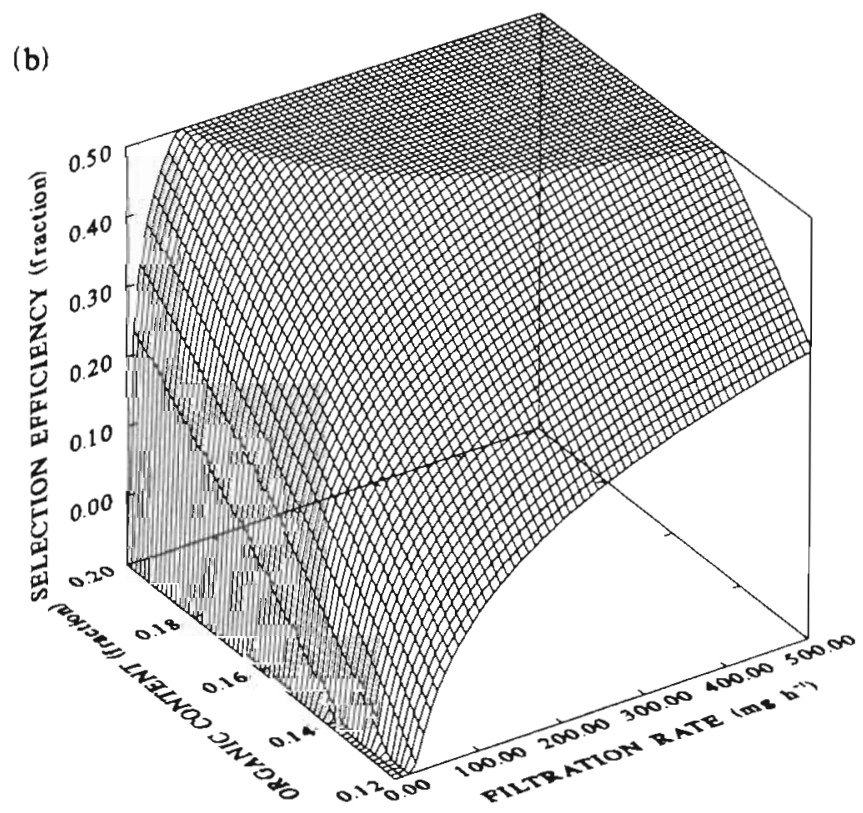

$$
\begin{aligned}
\text { NAEFO }= & 1.28( \pm 0.12)+0.96( \pm 0.09) \text { NOSE } \\
& -8.00( \pm 0.86) O C
\end{aligned}
$$

where $r^{2}=0.98$, residual $d f=11$, and $p<0.001$. This indicates how $N A E F O$ increased in positive relation with NOSE, but varied in negative relation with $O C$, so that the highest net absorption efficiencies were recorded when mussels were feeding upon seston with the lowest $O C$.

Net energy balance ( $N E B_{i} \mathrm{~J} \mathrm{~h}^{-1}$ ) increased with TPM in a relationship that was best described by the allometric equation:

$\left.N E B=10.064(0.006,0.639) \times T P M^{1.59( \pm 0.62)}\right]-10$

where $r^{2}=0.68$, residual $d f=12$, and $p<0.001$. This relation is illustrated in Fig. 7 , showing no indication that the increase in $N E B$ was beginning to slow at the highest recorded food availabilities. Further, as also illustrated in Fig. 7, and as has been confirmed by stepwise regression, the interrelations described above served to maintain $N E B$ independent of observed vari-

Fig. 4. Mytilus edulus. Net organic selection efficiency in relation to both the organic content of available seston and filtration rate in mussels standardised to $1 \mathrm{~g}$ dry flesh weight: (a) original data, and (b) function plot fitted by least squares; refer to Eq. (5) in 'Results' for parameters and significance level

Net absorption efficiency from filtered organics (NAEFO; fraction) was associated both with NOSE and $O C$, according to separate relations that were best described by the linear equation:

\section{DISCUSSION}

This is the first study to document each component process of nutrient acquisition through natural tidal variations of food availability in any benthic filterfeeder Very different responses have recently been observed in bivalves feeding upon natural suspensions of low organic content, rather than upon artificial ex- 
(a)

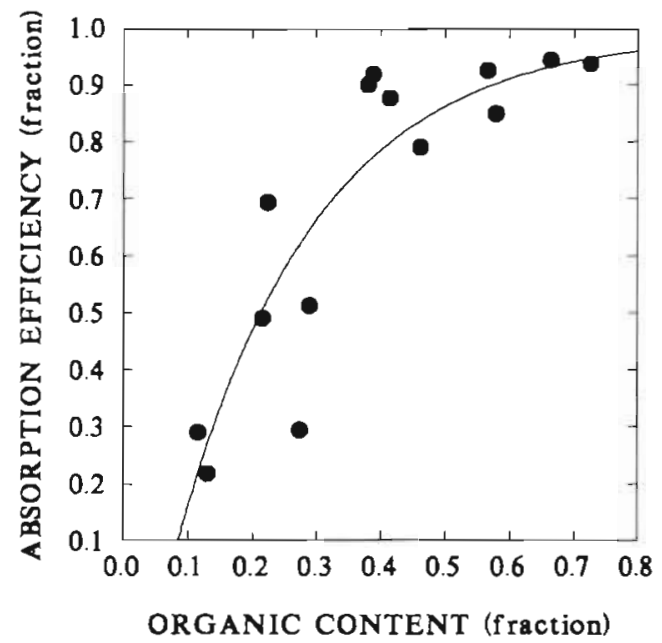

(b)

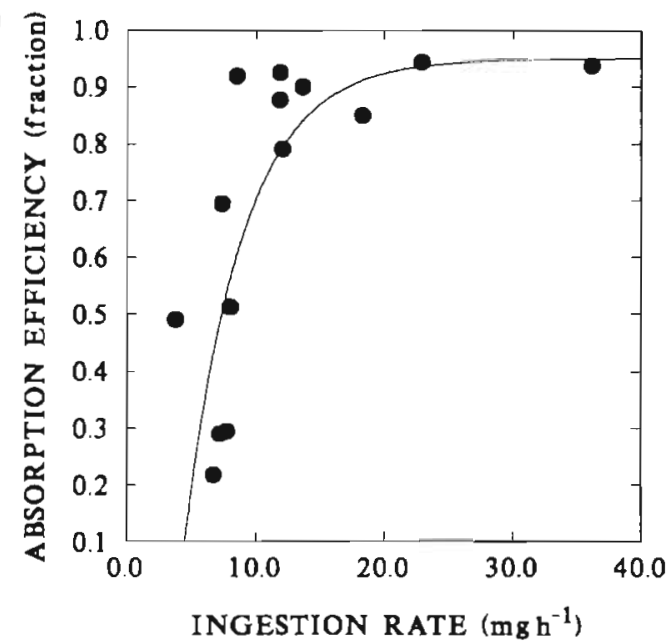

Fig. 6. Mytilus edulis. Absorption efficiency fron ingested organics in relation to both (a) organic content of ingested matter and (b) ingestion rate in mussels standardised to $1 \mathrm{~g}$ dry flesh weight. Data are the mean of separate determinations upon 10 replicate mussels. Lines were fitted by least squares; refer to Eqs. (6) \& (7) in 'Results' for parameters and significance levels

perimental diets (see 'Introduction'). Therefore, it should not be surprising that interrelations documented here for the mussel Mytilus edulis $\mathrm{L}$. are novel and appear to contradict many earlier findings.

To summarise our results, combining all data from both neap and spring tides, the $O C$ of available seston decreased with increasing abundance of up to about $90 \mathrm{mg}$ TPM. Throughout this variation, $C R$ increased with TPM (Eq. 2). This did not reflect any 'gut-filling' response following prolonged emersion, for $C R$ was independent of how long the mussel had been immersed. Further, pseudofaeces production rate remained a constant fraction of about $0.93 \times F R$, so that ingestion rate showed no signs of stabilising at even the highest food availabilities (Eq. 3, Fig. 3). Most significant was the observation that NOSE, with which filtered organics were selectively retained for ingestion, increased rapidly with $F R$. This increase was much faster for mussels feeding upon seston of higher $O C$ than of lower $O C$ (Eq. 5, Fig. 4). The result was that the $O C I$ increased with feeding rate (Fig. 5). And, because the NAEIO increased with OCI (Eq. 6, Fig. 6a), net NOAR and NEB remained independent of the decreasing $O C$ within particles that were available at increasingly higher concentrations (Fig. 7).

Increased $C R$ at higher $T P M$ and proportionally constant rejection of filtered material as pseudafaeces are consistent with recent laboratory studies in different bivalve species, suggesting that high rates of clearance and pseudofaeces production will maximise energy gain when feeding upon natural suspensions, offering the potential for pre-ingestive selection, but not when such selection is irrelevant (Iglesias et al. 1992, Navarro et al. 1992, Bayne et al. 1993). Exact relations may vary according to species, physiological status and food availability. Positive correlations have recently been described between the TPM of natural seston and $C R$ in both Mytilus edulis (Newell \& Shumway 1993) and Cerastoderma edule (Iglesias et al 1992). Alternatively, Barillé \& Prou (1994) reported that

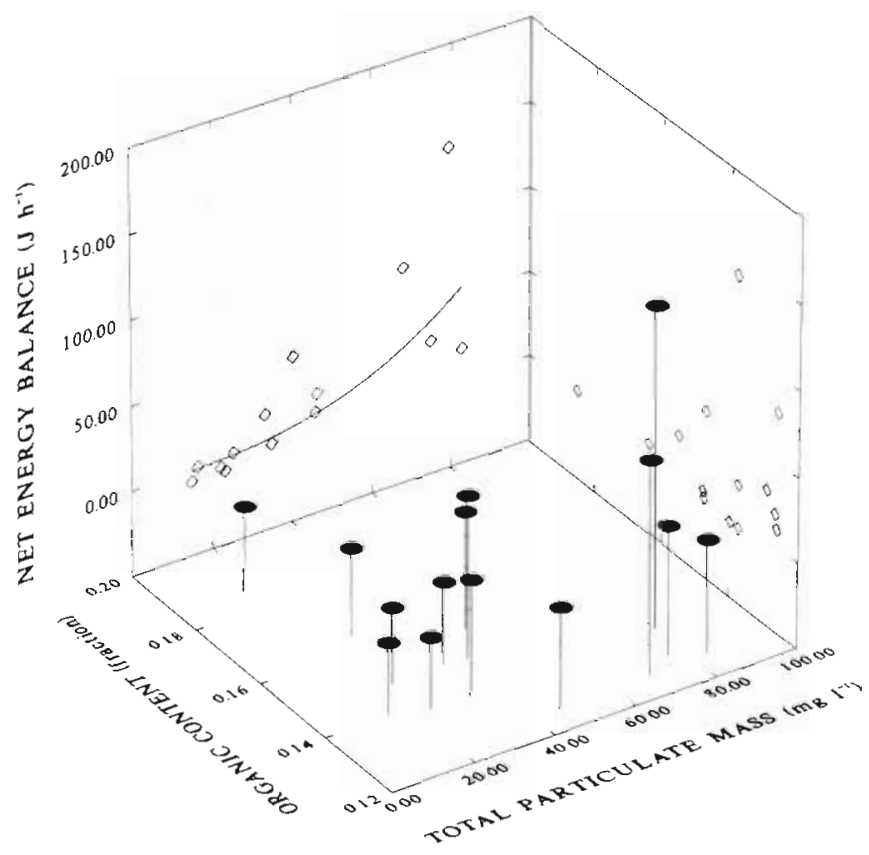

Fig. 7 Mytilus edulis. Net energy balance in relation to both the organic content and total particulate mass of available seston in mussels standardised to $1 \mathrm{~g}$ dry flesh weight. Data are the mean of separate determinations upon 10 replicate mussels. Line was fitted by least squares; refer to Eq. (8) in 'Results' for parameters and significance level 
$C R$ in Crassostrea gigas is maintained high but constant when feeding upon natural seston at TPMs of up to $50 \mathrm{mg} \mathrm{l}^{-1}$, before decreasing with further increases in TPM. An upper limit to the rate of particle processing is generally acknowledged in all species (Widdows et al. 1979, Bayne \& Newell 1983). Therefore, we anticipated that $C R$ in $M$. edulis would ultimately have decreased at higher TPMs than were experienced in the present study.

Working coincidentally with the present study, Prou et al. (1994) used an electronic sensor to monitor relative turbidity and thereby average rates of feeding $\left(1 \mathrm{~h}^{-1}\right)$ in response to the same natural variations in seston concentration among a single group of approximately 250 Mytilus edulis that were maintained collectively within a common raceway (65 l volume, with a through-flow of $101 \mathrm{~min}^{-1}$ ). Fig. 8 of Prou et al. (1994) indicated that clearance rate $\left(1 \mathrm{~h}^{-1}\right)$ increased with seston concentration. However, both the average clearance rate and influence of seston concentration recorded by Prou et al. (1994) were lower than present findings based upon the direct collection of biodeposits from individual $M$. edulis (average of $1.4 \mathrm{vs} 2.6 \mathrm{l} \mathrm{h}^{-1} \mathrm{~g}^{-1}$ dry tissue weight and an overall increase with TPM of 0.5 vs $2.5 \mathrm{l} \mathrm{h}^{-1} \mathrm{~g}^{-1}$ dry tissue weight, respectively). A similar reduction in clearance rates was found in the oyster Crassostrea gigas compared under identical circumstances (Barillé \& Prou 1994). These differences presumably reflect progressive particle depletion and secondary filtration of water as seawater passes over a population of shellfish (Fréchette et al. 1992) and possibly also a higher proportion of inactive animals when maintained together under raceway conditions (Barillé \& Prou 1994)

Our finding that $R R$ varied in strong positive relation with FR (Eq. 3; $\mathrm{r}^{2}=0.99$ ) is not consistent with earlier suggestions that the threshold TPM above which pseudofaeces are produced coincides with a maximum ingestion rate (Winter 1978, Widdows et al. 1979). Instead, as has been reported earlier for Mytilus edulis feeding mainly upon natural seston (Kiorboe et al. 1980), we saw that both $R R$ and $I R$ increased across the full range of seston availability. However, with increasing food availability above loads experienced here, we anticipated that $I R$ would reach maximal values, associated with reduced $C R$ and/or an increase in the ratio $R R \div F R$, as have both been observed in $M$. edulis feeding upon pure cultured algae (Foster-Smith 1975).

Our observation that $F R$ was a primary determinant of NOSE (Eq. 5, Fig. 4) has not previously been reported for any other filter-feeder, and appears to be of great significance in Mytilus edulis. The result was that as $F R$ increased, the $O C I$ was increasingly enriched by up to 5 times the $O C$ of filtered particles (Fig. 5). Past studies have reported pre-ingestive selec- tion (see 'Introduction'), but not that the associated efficiency of selection increased with FR. Indeed, neither Kiørboe et al. (1980) nor Prins et al. (1991) observed any effects of food availability on the efficiency of organic selection in $M$. edulis. However, as acknowledged by Prins et al. (1991), both of those studies made their comparisons on the basis of chlorophyll a within cultured alga added to silt suspensions, which limited the sensitivity of their analyses. We do not suggest here that NOSE will increase with FR in all suspension-feeding bivalves. For example, NOSE was independent of large variations in the TPM of mainly natural seston available to Cerastoderma edule (Iglesias et al. 1992, Navarro et al. 1992). This difference appears to be related to contrasting behaviour, whereby $I R$ is much more closely regulated in $C$. edule than in $M$. edulis, primarily through adjustments of $C R$ (Foster-Smith 1975, Bayne \& Newell 1983).

We have confirmed here that NOSE may vary according to seston composition (Eq. 5, Fig. 4), with past studies suggesting a hyperbolic relation with the $O C$ of filtered material (see 'Introduction') Mucus represents a roughly constant fraction of $R R$ (Hawkins unpubl..). Therefore, assuming an unchanging potential for sorting, and given a particle $O C$ of up to only 0.2 , it seems likely that relative enrichment of pseudofaeces by mucus is the reason why NOSE decreased with the $O C$ of seston available in the present study (Fig. 4).

The mechanisms effecting selective rejection within pseudofaeces are poorly understood. Cell shape, electrical charge and chemical cues such as algal ectocrines may be significant (Newell et al. 1989, Ward \& Targett 1989, Kemp et al. 1990, Prieur et al. 1990), but these factors are unlikely to explain the increase in NOSE with FR. Behavioural or morphological variables concerning the labial palps and possibly the gills seem more likely. We know that labial palps are the primary site of particle sorting among suspension-feeding bivalves (Barillé 1994, Ward et al. 1994), that mussels may adapt palp size following transplantation to sites of different turbidity (Essink et al. 1989), and that positive correlations exist between the size of those palps and the efficiency of associated selection (Kiørboe \& Møhlenberg 1981).

A further finding important to our overall understanding of suspension-feeding behaviour in Mytilus edulis was that the NAEIO increased in highly significant positive linear relation with $O C I$ (Eq. 6, Fig. 6a). Positive relations have previously been observed between net absorption efficiency and the $O C$ of seston ingested by mussels feeding upon laboratory diets, available, at environmentally unrealistic concentrations, below the threshold at which pseudofaeces are produced (Hawkins et al. 1986, Navarro et al. 
1992). Our findings indicate that this interrelation continues at much faster rates of feeding in the natural environment. Irrespective of feeding rate, we attribute the dependence of NAEIO on OCI to metabolic faecal losses incurred through normal digestive processes, which include materials lost from mussels and other animals following secretion, exocytosis and/or abrasion in the gut (Hawkins et al. 1983, Hawkins \& Bayne 1992). These losses may represent a constant fraction of the mass ingested (Hawkins et al. 1990, Navarro et al. 1994), and are thus of greater proportional influence upon the net efficiency of absorption from ingested matter of low $O C$.

As a result of the above interrelations, NAEIO increased with $I R$ (Eq. 7, Fig. 6b). This is in contrast to previous findings in mussels feeding below the pseudofaeces threshold. Then, NAEIO decreased with $I R$, presumably because faster associated gut passage times reduced the opportunity for digestion and absorption (cf. Bayne et al. 1984, 1987, 1989, Navarro et al. 1992). Furthermore, the NAEFO was highest when feeding upon seston with the lowest $O C$, and this occurred despite the positive relation between net absorption efficiency and food $O C$ when feeding upon suspensions available below the pseudofaeces threshold (Hawkins et al. 1986, Navarro et al. 1992). These 2 differences clearly illustrate the physiological significance of collective positive relations described here between $C R$ and TPM, IR and CR, NOSE and FR, OCI and NOSE, and NAEIO and $O C l$.

Considering the integrated physiological implications of these interrelations, then although the $O C$ of seston decreased as TPM increased, NEB continued to increase at the highest recorded food availabilities of up to about 90 total dry $\mathrm{mg} \mathrm{l}^{-1}$ (Fig 7). The highest $N E B$ computed here was $140 \mathrm{~J} \mathrm{~h}^{-1}$. This is greater than has previously been recorded for mussels in their natural environment, but it is important to realise that these high values correspond with transient maxima in seston availability, and only occurred during the fastest current speeds associated with spring tides. Therefore, they are well in excess of the daily average. To compute that daily average, we estimated the average TPM of available seston at hourly intervals, using the data illustrated in Fig. 2 for both neap and spring tides, to estimate a cycle in TPM that is representative for mussels submerged throughout 9 of every $12 \mathrm{~h}$ over the longer term. We then used the positive relation between TPM and NEB ( $\mathrm{J} \mathrm{h}^{-1}$; Eq. 9) to compute hourly net energy balances whilst the mussels were submerged in the natural environment at Les Chapus. We also assumed a net energy loss of $0.9 \mathrm{~J} \mathrm{~g}^{-1}$ tissue dry weight $\mathrm{h}^{-1}$ during periods of aerial exposure as reported for Mytilus edulis by Shick et al. (1988). These computations are illustrated in Fig. 8, and result in an integrated $N E B$ of $263 \mathrm{~J} \mathrm{~d}^{-1}$ Given that mussel tissue contains about $20 \mathrm{~J} \mathrm{mg}^{-1}$ total dry weight, this represents a growth rate of $13.2 \mathrm{mg}$ or $1.3 \% \mathrm{~d}^{-1}$ for a mussel of $1 \mathrm{~g}$ dry flesh weight. Previous direct measures of tissue growth over a full year have shown that transplanted $M$. edulis grew fastest during the months of May and June in the bay of Marennes-Oléron, when mussels with an average of $0.25 \mathrm{~g}$ dry flesh weight grew an average of at least $6 \mathrm{mg}$ or $2.4 \% \mathrm{~d}^{-1}$ (Boromthanarat \& Deslous-Paoli 1988). If one assumes the theoretical weight exponent for growth of 0.75 , then these growth rates observed directly in the field are equivalent to about $17 \mathrm{mg}$ or $1.7 \% \mathrm{~d}^{-1}$ in a mussel of $1 \mathrm{~g}$ dry flesh weight. Clearly, our predicted growth of $1.3 \% \mathrm{~d}^{-1}$ for animals of the same size at the same time of year is
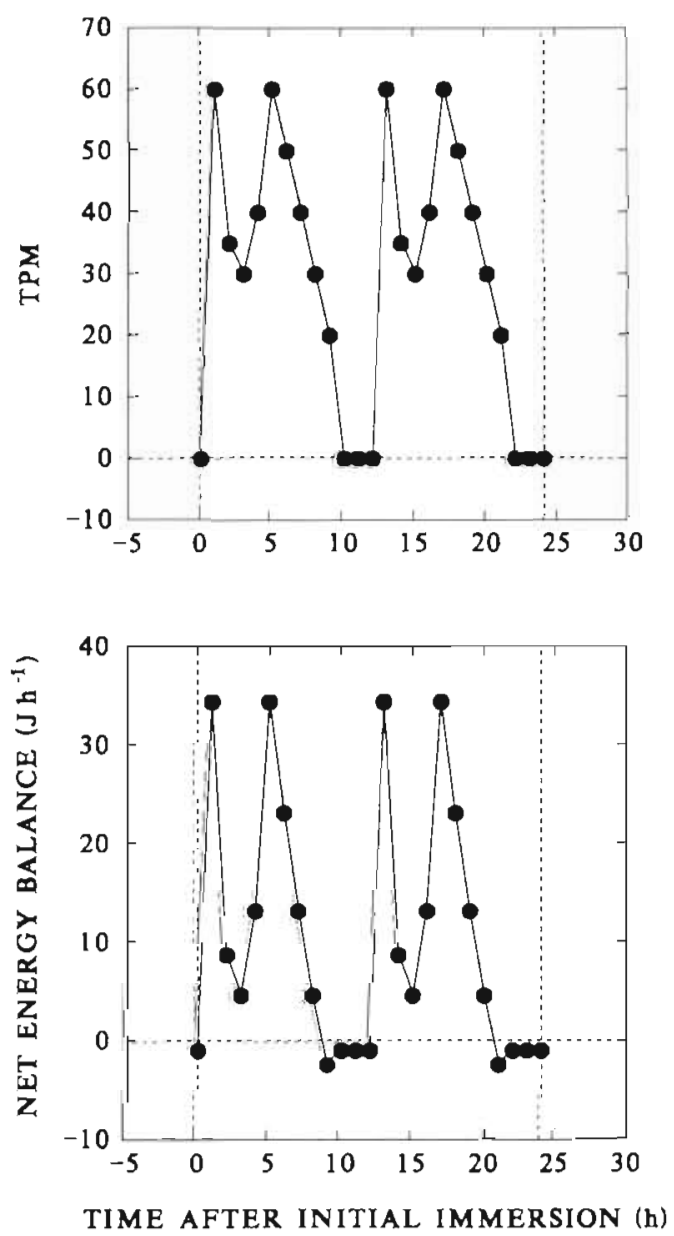

Fig. 8. Mytilus edulis. Average total particulate mass (TPM; $\mathrm{mg}^{-1}$ ) available as seston and hourly net energy balance in relation to time after initial immersion over $24 \mathrm{~h}$ in mussels submerged for 9 of every $12 \mathrm{~h}$ within the intertidal zone at Les Chapus, France. TPM was calculated as the average between those illustrated for neap tides and spring tides in Fig. 1. NEB was calculated using the average TPM values illustrated here and Eq. (9) relating NEB and TPM as described in 'Results' 
no higher than these direct measures of maximal growth, which lends confidence to the interrelationships and energy fluxes that are presented here.

These findings therefore help us to understand the means by which Mytilus edulis grow within turbid nearshore waters. In particular, we have described how clearance rates varied in positive relation with rapid tidal fluctuations in the availability of natural seston, and how net organic selection efficiency increased markedly with the rate of filtration, with the result that the organic content of ingesta and associated efficiencies and rates of organic absorption each increased with feeding rate. These are novel observations that have profound implications on our understanding of nutritional requirements and the role of suspensionfeeders in coastal ecosystem dynamics (see 'Introduction'). They also build upon earlier appreciation of the general significance of particle selection (Kiørboe et al. 1980, Kiorboe \& Møhlenberg 1981; and see 'Introduction'), providing significant new insights on how filterfeeders may grow so quickly despite the increasing 'dilution' of available food by silt resuspended within higher concentrations of natural seston.

Acknowledgements. This work represents part of Strategic Research Project 3 ('Marine Biodiversity') of the Plymouth Marine Laboratory, a component of the UK Natural Environment Research Council, and was supported by the Commission of the European Communities (Contract No. AQ 2500).

\section{LITERATURE CITED}

Asmus H, Asmus RM (1993) Phytoplankton-mussel bed interactions in intertidal ecosystems. In: Dame RF (ed) Bivalve filter feeders in estuarine and coastal ecosystem processes. Springer-Verlag, Berlin, p 57-84

Asmus RM, Asmus H (1991) Mussels beds: limiting or promoting phytoplankton? J exp mar Biol Ecol 148:215-232

Barillé L (1994) Observations des éléments structuraux intervenant dans les mécanismes de nutrition préingestuve chez l'huitre japonaise Crassostrea gigas. Halious 23 : $125-137$

Barillé L, Bougrier S, Geairon P, Robert JM (1994) Experimental feeding of the oyster Crassostrea gigas (Thunberg) with three populations of different-sized modes of the diatom Hasslea ostrearia (Simonsen). Oceanol Acta 17. $201-210$

Barillé L, Prou J (1994) Modeling Japanese oyster physiological processes under natural tidal variations in suspended particulate matter. Comm Meet int Counc Explor Sea CMICES/F:22:1-12

Barillé L, Prou J, Héral M, Bougrier S (1993) No influence of food quality, but ration-dependent retention efficiencies in the oyster Crassostrea gigas. J exp mar Biol Ecol 171:91-106

Bayne BL (1993) Feeding physiology of bivalves: time dependence and compensation for changes in food availability. In: Dame RF (ed) Bivalve filter feeders in estuarine and coastal ecosystem processes. Springer-Verlag, Berin, p 1-24

Bayne BL, Hawkins AJS (1992) Ecological and physiological aspects of herbivory in benthic suspension-feeding molluscs. In: John DM, Hawkins SJ, Price JH (eds) Plant- anmal interaction in the marine benthos. Systematics Association Special Volume No 46, Clarendon Press, Oxford, p 265-288

Bay ne BL, Hawkins AJS, Navarro E (1987) Feeding and digestion by the common mussel Mytilus edulis $L$. (Bivalvia: Mollusca) in mixtures of silt and alcal cells at low concentrations. J exp mar Biol Ecol 111:1-22

Bayne BL, Hawkins AJS, Navarro E. Iglesias JIP (1989) The effects of seston concentration on feeding, digestion and growth in the mussel Mytilus edulis. Mar Ecol Prog Ser 55: $47-54$

Bayne BL, Iglesias JIP, Hawkins AJS, Navarro E, Héral M, Deslous-Paoli JM (1993) Feeding behaviour of the mussel, Mytilus edulis L.; responses to variations in both quantity and organic content of seston. I mar biol Ass UK 73: $813-829$

Bayne BL, Klumpp DW. Clarke KR (1984) Aspects of feeding, including estimates of gut residence time, in three mytilid species (Bivalvia, Mollusca) at two contrasting sites in the Cape Peninsula, South Africa. Oecologia 64:26-33

Bayne BL, Newell RC (1983) Physiological energetics of marine molluscs. In: Wilbur KM, Saleuddin AS (eds) The Mollusca, Vol 4. Academic Press, New York, p 407-515

Bayne BL, Widdows J (1978) The physiological ecology of two populations of Mytilus edulis L. Oecologia 37:137-162

Boromthanarat S, Deslous-Paoli JM (1988) Production of Mytilus edulis L. reared on bouchets in the bay of Marennes-Oleron: comparison between two methods of culture. Aquaculture 72:255-263

Bncelj VM, Malouf RE (1984) Influence of algal and suspended sediment concentrations on the feeding physiology of the hard clam Mercenaria mercenaria. Mar Biol 84:155-165

Cloern JE (1982) Does benthos control phytoplankton biomass in south San Francisco Bay? Mar Ecol Prog Ser 9 $191-202$

Cranford PJ, Gordon DC Jr (1992) The influence of dilute clay suspensions on sea scallop (Placopecten magellanicus) feeding activity and tissue growth. Neth $J$ Sea Res 30 $107-120$

Cranford PJ, Grant J (1992) Particle clearance and absorption of phytoplankton and detritus by the sea scallop Placopecten magellanicus (Gmelin). J exp mar Biol Ecol 137:105-121

Cranford PJ, Hargrave BT (1994) In situ time-series measurement of ingestion and absorption rates of suspension-feeding bivalves: Placopecten magellanicus. Limnol Oceanogr 39:730-738

Dame RF (1993) The role of bivalve filter teeder material fluxes in estuarine ecosystems. In: Dame RF (ed) Bivalve filter feeders in estuarine and coastal ecosystem processes. Springer-Verlag, Berlin, p 245-270

Dame RF, Zingmark R, Stevenson H, Nelson D (1980) Filter feeder coupling between the estuarine water column and benthic subsystems. In: Kennedy VS (ed) Estuarine perspectives. Academic Press, New York, p 521-526

Davids $C$ (1964) The influence of suspensions of micro-organisms of dufferent concentrations on the pumping and retention of food by the mussel (.Mytilus edulis L.). Neth J Sea Res 2.233-249

Deslous-Paoli JM, Boromthanarat S, Héral M, Boromthanarat W. Razet D (1990) Energy budget of a Mytilus edulis L. population during its first year on bouchots in the bay of Marennes-Oléron. Aquaculture 91:49-63

Deslous-Paoli JM, Lannou AM, Geairon P, Bougrier S, Raillard O. Héral M (1992) Effects of the feeding behaviour of Crassostrea gigas (Bivalve Molluscs) on the biosedimenta. tion of natural particulate matter. Hydrobiologia 231. $85-91$ 
Doering PH, Oviatt CA (1986) Application of filtration rate models to field populations of bivalves: an assessment using experimental mesocosms. Mar Ecol Prog Ser 31: $265-275$

Essink K, Tydeman P, de Koning F, Kleef HL (1989) On the adaptation of the mussel Mytilus edulis $\mathrm{L}$. to different environmental suspended matter concentrations. In: Klekowski RZ, Stycrynska-Jurewicz E, Falkowski L (eds) Biochemical and physiological adaptation in marine organisms. 21st Eur Mar Biol Symp. Ossolineum, Gdansk, p 41-51

Fegley SR, MacDonald BA, Jacobsen TR (1992) Short-term variation in the quantity and quality of seston available to benthic suspension feeders. Estuar coast Shelf Sci 34: $393-412$

Foster-Smith RL (1975) The effect of concentration of suspension and inert material on the assimilation of algae by three bivalves. J mar biol Ass UK 55:411-418

Fréchette M, Aitken AE, Pagé L (1992) Interdependence of food and space limitation of a benthic suspension feeder: consequences for self-thinning relationships. Mar Ecol Prog Ser 83:55-62

Griffiths RJ (1980) Natural food availability and assimilation in the bivalve Choromytilus meridionalis. Mar Ecol Prog Ser 3:151-156

Hawkins AJS, Bayne BL (1991) Nutrition of marine mussels: factors influencing the relative utilizations of protein and energy. Aquaculture 94:177-196

Hawkins AJS, Bayne BL (1992) Physiological processes, and the regulation of production. In: Gosling $E$ (ed) The mussel Mytilus: ecology, physiology, genetics and culture. Elsevier Science Publishers BV, Amsterdam, p 171-222

Hawkins AJS, Bayne BL, Clarke KR (1983) Co-ordinated rhythms of digestion, absorption and excretion in Mytilus edulis (Bivalvia: Mollusca). Mar Biol 74:41-48

Hawkins AJS, Bayne BL, Mantoura RFC, Llewellyn CA, Navarro E (1986) Chlorophyll degradation and absorption throughout the digestive system of the blue mussel Mytilus edulis L. J exp mar Biol Ecol 96:213-223

Hawkins AJS, Navarro E, Iglesias JIP (1990) Comparative allometries of gut content, gut passage time and metabolic faecal loss in Mytilus edulis and Cerastoderma edule. Mar Biol 105:197-204

Hawkins AJS, Widdows J, Bayne BL (1989) The relevance of whole-body protein metabolism to measured costs of maintenance and growth in Mytilus edulis. Physiol Zool 62:745-763

Héral M (1993) Why carrying capacity models are useful tools for management of bivalve molluscs culture. In: Dame RF (ed) Bivalve filter feeders in estuarine and coastal ecosystem processes. Springer-Verlag, Berlin, p 455-478

Héral M, Deslous-Paoli JM, Sornin JM (1983) Transferts énergétiques entre l'huitre Crassostrea gigas et la nourriture potentielle disponible dans un bassin ostréicole: premières approches. Océanis 9:169-194

Herman PMJ (1993) A set of models to investigate the role of benthic suspension feeders in estuarine ecosystems. In: Dame RF (ed) Bivalve filter feeders in estuarine and coastal ecosystem processes. Springer-Verlag, Berlin, $p$ $421-454$

Iglesias JIP, Navarro E, Alvarez Jorna P, Armentia I (1992) Feeding, particle selection and absorption in cockles Cerastoderma edule (L.) exposed to variable conditions of food concentration and quality. J exp mar Biol Ecol 162:177-198

Jørgensen CB (1966) The biology of suspension feeding. Pergamon Press, Oxford

Kemp PF, Newell SY, Krambeck C (1.990) Effects of filterfeeding by the ribbed mussel Geukensia demissa on the water-column microbiota of a Spartina alterniflora saltmarsh. Mar Ecol Prog Ser 59:119-131

Kiorboe T, Mohlenberg F (1981) Particle selection in suspension-feeding bivalves. Mar Ecol Prog Ser 5:291-296

Kiorboe T, Møhlenberg F, Nøhr O (1980) Feeding, particle selection and carbon absorption in Mytilus edulis in different mixtures of algae and resuspended bottom material. Ophelia 19:193-205

Kiorboe T, Møhlenberg F, Nohr O (1981) Effect of suspended bottom material on growth and energetics in Mytilus edulis. Mar Biol 61:283-288

Lucas MI, Newell RC, Shumway SE, Seiderer LJ, Bally R (1987) Partucle clearance and yield in relation to bacterioplankton and suspended particulate availability in estuarine and open coast populations of the mussel Mytilus edulis. Mar Ecol Prog Ser 36:215-224

Mohlenberg F, Kiørboe $\uparrow(1981)$ Growth and energetics in Spisula subtruncata (Da Costa) and the effect of suspended bottom material. Ophelia 20:79-90

Navarro E, Iglesias JIP (1993) Infaunal filter-feeding bivalves and the physiological response to short-term fluctuations in food availability. In: Dame RF (ed) Bivalve filter feeders in estuarine and coastal ecosystem processes. SpringerVerlag, Berlin, p 25-56

Navarro E, Iglesias JIP, Ortega MM (1992) Natural sediment as a food source for the cockle Cerastoderma edule (L.) effect of variable particle concentration on feeding, digestion and the scope for growth. J exp mar Biol Ecol 156: $69-87$

Navarro E, Iglesias JIP, Ortega MM, Larretxea X (1994) The basis for a functional response to variable food quantity and quality in cockles Cerastoderma edule (Bivalvia, Cardiidae). Physiol Zool 67:468-496

Newell CR, Shumway SE (1993) Grazing of natural particulates by bivalve molluscs: a spatial and temporal perspective. In: Dame RF (ed) Bivalve filter feeders in estuarine and coastal ecosystem processes. Springer-Verlag, Berlin, p 85-148

Newell CR, Shumway SE, Cucci TL, Selvin R (1989) The effects of natural seston particle size and type on feeding rates, feeding selectivity and food resource availability for the mussel Mytilus edulis Linnaeus, 1758 at bottom culture sites in Maine. J Shellfish Res 8:187-196

Newell RIE, Jordan SJ (1983) Preferential ingestion of organic material by the American oyster Crassostrea virginica. Mar Ecol Prog Ser 13:7-53

Officer CB, Smayda TJ, Mann R (1982) Benthic filter feeding: a natural eutrophication control? Mar Ecol Prog Ser 9:203-210

Prieur D, Mevel G, Nicolas JL, PIusquellec A, Vigneulle M (1990) Interactions between bivalve molluscs and bacteria in the marine environment. Oceanogr mar Biol A Rev 28: $277-352$

Prins TC, Smaal AC (1989) Carbon and nitrogen budgets of the mussel Mytilus edulis L. and the cockle Cerastoderma edule (L.) in relation to food quality. Scientia mar 53 : $477-482$

Prins TC, Smaal AC, Pouwer AJ (1991) Selective ingestion of phytoplankton by the bivalves Mytilus edulis L. and Cerastoderma edule (L.). Hydrobiol Bull 25:93-100

Prou J, Barillé L, Héral M, Ratiskol G, Soletchnik P, Bougrier S, Razet D, Geairon P (1994) Influence du cycle semidiurne et vives-eaux mortes-eaux sur la disponibilité du material particulaire et son utilisation par une population de Mytilus edulis. Haliotis 23:139-153

Riisgård HU (1988) Efficiency of particle retention and filtration rate in 6 species of the northeast American bivalves. Mar Ecol Prog Ser 45:217-223 
Rodhouse PG, Roden CM, Brunnell GM, Hensey MP, McMahon $T$. Ottway B, Ryan TH (1984) Food resource, gametogenesis and growth of Mytilus edulis on the shore and in suspended culture: Killary Harbour, Ireland. J mar biol Ass UK 64:513-529

Shuck JM, Widdows J, Gnaiger E (1988) Calorimetric studies of behaviour, metabolism and energetics of sessile intertidal animals. Am Zool 28:161-181

Smaal AC, Prins TC (1993) The uptake of organic matter and the release of inorganic nutrients by bivalve suspension feeder beds. In: Dame RF (ed) Bivalve filter feeders in estuarine and coastal ecosystem processes. Springer-Verlag, Berlin, p 271-298

Smaal AC, Verhagen JHG, Coosen J, Haas HA (1986) Interaction between seston quantity and quality and benthic suspension feeders in the Oosterschelde. The Netherlands. Ophelia 26:385-399

Ward JE, Newell RIE, Thompson RJ, MacDonald BA (1994) In vivo studies of suspension-feeding processes in the eastern oyster, Crassostrea virginica (Gmelin). Biol Bull 186:221-240

This article was submitted to the editor
Ward JE, Targett NM (1989) Influence of marine microalgal metabolites on the feeding behaviour of the blue mussel Mytilus edulis. Mar Biol 101:313-321

Widdows J, Fieth P, Worrall CM (1979) Relationships between seston, avajlable food and feeding activity in the common mussel Mytilus edulis. Mar Biol 50:195-207

Winter JE (1973) The filtration rate of Mytilus edulis and its dependence on algal concentration, measured by a continuous automatic recording apparatus. Mar Biol 22: $317-328$

Winter JE (1976) Feeding experiments with Mytilus edulis L at small laboratory scale. II. The influence of suspended silt in addition to algal suspensions on growth. In: Persoone $\mathrm{G}$, Jaspers $\mathrm{E}$ (eds) Research in mariculture at laboratory-and pilot-scale, Vol 1. 10th Eur Mar Biol Symp. Universa Press, Wetteren, p 583-600

Winter JE (1978) A review of the knowledge of suspensionfeeding in lamellibranchiate bivalves, with special reference to artificial aquaculture systems. Aquaculture 13: $1-33$

Manuscript first received: December 30, 1994

Revised version accepted: July 21, 1995 